\title{
Analysis of Metal Content of Lead (Pb) in Sediment and on Gonggong Snail at Coastal of Senggarang Besar Tanjungpinang City on 2016
}

\author{
Erpina Santi Meliana Nadeak ${ }^{1}$, Retno Sevtaviana ${ }^{2}$, Veronika Amelia ${ }^{3}$ and Novian Aldo \\ ${ }^{1,2,3}$ Health Environmental, Poltekkes Kemenkes Tanjungpinang, Indonesia \\ santi deaks@yahoo.co.id ${ }^{1}$ \\ rsevtaviana@gmail. $\mathrm{com}^{2}$ \\ veronikaameliasimbolon@gmail. $\mathrm{com}^{3}$ \\ ${ }^{4}$ Nursing, Poltekkes Kemenkes Tanjungpinang, Indonesia \\ novian_aldotpi@yahoo. $\mathrm{com}^{4}$
}

\begin{abstract}
The Observation of heavy metals in sediments and gongong snails in the Coastal of Senggarang in Tanjungpinang city has been conducted in May-June 2016. The red mud pool located on Senggarang is a pool containing liquid waste excavation of bauxite mine predicted containing any heavy metals such as lead. The liquid wastes come into the waterworks, settle and then turn into a sediment. Senggarang is one of the major producing gongong snails which are also known as a typical food for Tanjungpinang community. The presence of heavy metal pollution that accumulates in the waterworks can contaminate humans as highest food chain. If a metal accumulates in the animals and plants tissues which are then consumed by humans, it concludes that humans as the highest food chain at food pyramid, the body of the humans will also accumulate the heavy metal. This can lead to a high risk to health. The aim of this study is to know the content of heavy metal content in sediments and gongong snails in the waterworks at Senggarang. This research is an analytic observational with cross sectional design. Sampling technique used purposive sampling in which the sediment and Gongong snails were taken at 3 areas that is commonly used by fisherman to take gongong snails. The Measurements of lead metal content used Atomic absorption spectrophotometer (AAS). The result of this study found that the average of Lead metal contained in gongong snails at $5: 39 \mathrm{mg} / \mathrm{kg}$ and sediment at $36.84 \mathrm{mg} / \mathrm{kg}$. This result has exceeded the quality standard ISO 7387: 2009 about the maximum limit of heavy metal contamination in food, and the standard of Sediment Quality Guidelines on the threshold Lead metal contamination in sediment for coastal and marine waters. Suggestion related to this research is to do actions and direct supervison toward bauxite excavation area in Senggarang and also conduct an analysis research of metal content of $\mathrm{Pb}$ to all types of marine life.
\end{abstract}

Keywords-Heavy metal, sediment, Gonggong Snail, Senggarang, $\operatorname{Lead}(\boldsymbol{P b})$

\section{INTRODUCTION}

Riau Archipelago is a province with a total area of $252601 \mathrm{~km}^{2}$, in which about $96 \%$ is ocean, and only about $4 \%$ is land area [5]; it has abundant and diverse marine life. The potential of marine fisheries in the
Riau Archipelago namely; shell, tuna fish, shrimp, tuna and seaweed. Senggarang is one of the producing area of Gongong Snails in TanjungpinangRiau Archipelago. It is proved from the residing community who are looking for Gonggong Snail (Strombus Canarium) for consumption and sale.

Senggarang coastal as one of area is filled with a variety of activities such as residential areas, fishing port and Mining. Department of Agriculture Forestry and Fisheries Marine Energy-Tanjungpinang in Riau Archipelago Province stated that Senggarang is one area that has been so long as illegal bauxite mining [8].

The presence of heavy metal pollution in coastal waterworks are necessary to have serious attention from various parties [9]. Because the exixtence of relatively little heavy metals in waters is very easily absorbed and biologically accumulated by plants or aquatic animals that will be involved in food network system.

The content of heavy metals in aquatic biota will usually increase through the time as it is bioaccumulative, so the water biota can be used as an indicator of metal pollution in waterworks. Heavy metals that pollute the environment is largely disseminated through the waterway, according [6].This process will be faster when entering the human body through the food chain.

If a metal is accumulated at the animals and plants tissues then consumed by humans, it can conclude that humans as the highest in the food chain of the food pyramid, the body of the humans will 
accumulate the heavy metal. Metal particles in the waterworks will settle in sediments and will be accumulated by the aquatic biota by the time and the growth of these organisms, if it is consumed by humans in large numbers, it will be at high risk for health (Sitepu, 2015).

Stated that the types of heavy metals contained in the tailings or red mud waste on bauxite mining in the region of Wacopek Bintan Island, Riau Archipelago Province are $\mathrm{Fe}, \mathrm{Ni}, \mathrm{Mn}, \mathrm{Zn}, \mathrm{Pb}, \mathrm{Cu}, \mathrm{Cd}$ and $\mathrm{Cr}$ [16]. Tailings which was seen as a red mud liquid, the water and mud mixed with sand known as the bauxite washing waste is flowed into sedimentation pools before it was flowed into the sea or into the environmental surrounding. According to Effendi in Zulfikar Research (2011), Lead (Pb) is kind of metals that until now has been unknown of it's role for animals, plants or other living creatures [16]. Heavy metals in the waterwoks will go down and settle at the bottom of waterwoks and then turn into sediment, this will lead feeding on the seabed such as shrimp, crab, and mussels to have a great opportunity to be infected by heavy metals that have been tied at the bottom of water. The exixtence of the influence and strong relationship between the content of heavy metal is caused by the concentration of the heavy metal in sediment that may effect to Gonggong Snail, since they live and feed on the base substrate [2].

Researcher conducted a preliminary survey on February, 29th 2016 toward the Gonggong meat gained from the residential area which also a place where Gongong Snail were taken from, prepared in the laboratory of Universitas Maritim Raji Ali Haji (UMRAH) then analyzed in Balai Teknik Kesehatan Lingkungan-Pengendalian Penyakit (BTKL-PP) Class I Batam, with the result of the content of metal lead $(\mathrm{Pb})$ 0:06 mg / L in 1 gram of Gonggong meat which is equivalent to $2.1 \mathrm{mg} / \mathrm{kg}$. This result indicated that $\mathrm{Pb}$ content in Gonggong meat already exceeded the limit based on ISO 7387: 2009 related to the maximum limitation of heavy metal Contamination in Food, which is $1.5 \mathrm{mg} / \mathrm{kg}$. Based on the explanation above, it is necessary to do further research for the analysis of metal content of lead in Sediments and Gongong Snail. The aim of this study was to determine the heavy metal content of lead in sediments and Gonggong Snail in the waterwork at Senggarang.

\section{METHODOLOGY}

This research is an observational analytic with cross sectional observation. This research was conducted in the residential area at the coastal Senggarang, the sample of preparation is conducted in the laboratory of marine science and fisheries of UMRAH, and lead metal content $(\mathrm{Pb})$ testing is conducted in BTKL-PP Class I Batam. This research used purposive sampling tecnique. The area sample was taken at three areas namely; area A (it is the farthest area to the ex- bauxite mine excavation in which Gonggong Snails were taken from). Area B (it is near to the residental area in which Gonggong Snails were taken from). Area C (it is the closest area to the ex- bauxite mine excavation in which Gonggong Snails were taken from)

The Sample of Gonggong Snails which were commonly found in the base of coastal water at Senggarang were taken at low tide. Gonggong Snails catched were put into sample place then taken to the laboratory for preparation an finally analyzied using Atomic Absorption Spectrophotometer (AAS).

Sediment samples were taken by using PVC pipe, then put into the sample place, preparation of sediment sample done and finally analyzied by using Atomic Absorption Spectrophotometer (AAS)

To find out the lead metal concentration measurement, it used the formula;

Actual concentration $(\mathrm{mg} / \mathrm{g})=[$ AAS Concentration $(\mathrm{mg} / \mathrm{L}) \times$ Volume (L) ] / Dry weight (g).

\section{RESULT AND DISCUSSION}

Senggarang which is part of the disrict of Tanjungpinang city has rich area especially with the sea and its marine products, the land of Senggarang around $\pm 1 \mathrm{~km}^{2}$ in wide. Senggarang has a population of 80 families. Most of them are fishermen.

There are some activities that can be found in Senggarang area such as settlement and fishing port, it also has excavated mine area called red mud which is a mixture of rainwater and waste generated from washing bauxite mine product that has not operated anymore during the last 2 years. However, before entering the Senggarang area there are still found 
active bauxite mining activites, located in the coastal suburb.

The average value of lead heavy metals $(\mathrm{Pb})$ in Gonggong meat and sediment at 3 areas where Gonggong Snail were taken from can be seen in Table 1 below;

TABLE I

THE AVERAGE VALUE OF LEAD HEAVY METALS (PB) CONTENT IN GONGGONG MEAT AND SEDIMENT AT THE SENGGARANG COASTAL

\begin{tabular}{|c|c|c|c|c|c|c|}
\hline $\begin{array}{l}\text { The } \\
\text { sampling } \\
\text { area }\end{array}$ & \multicolumn{2}{|c|}{$\begin{array}{c}\text { Dry weath } \\
\text { (g) }\end{array}$} & \multicolumn{2}{c|}{$\begin{array}{c}\text { The content } \\
\text { of Pb } \\
\text { (mg/L) }\end{array}$} & \multicolumn{2}{c|}{$\begin{array}{c}\text { The content } \\
\text { of Pb } \\
(\mathbf{m g} / \mathbf{k g})\end{array}$} \\
\cline { 2 - 7 } & $\begin{array}{c}\text { Gon } \\
\text { ggo } \\
\text { ng }\end{array}$ & $\begin{array}{c}\text { Sedim } \\
\text { ent }\end{array}$ & $\begin{array}{c}\text { Gon } \\
\text { ggo } \\
\text { ng }\end{array}$ & $\begin{array}{c}\text { Sedim } \\
\text { ent }\end{array}$ & $\begin{array}{c}\text { Gon } \\
\text { ggo } \\
\text { ng }\end{array}$ & $\begin{array}{c}\text { Sedi } \\
\text { ment }\end{array}$ \\
\hline A & 1.02 & 5.03 & 0.14 & 0.85 & 4.63 & 29.40 \\
\hline B & 1.03 & 5.02 & 0.14 & 1.14 & 4.76 & 39.76 \\
\hline C & 1.06 & 5.01 & 0.20 & 1.19 & 6.77 & 41.37 \\
\hline Average & 1.04 & 5.02 & 0.16 & 1.06 & 5.39 & 36.84 \\
\hline
\end{tabular}

The Sediment quality guidelines is used as The quality standard of $\mathrm{Pb}$ on solids or sediment in amount of $30.2 \mathrm{mg} / \mathrm{kg}$, while the standard of ISO 7387: 2009 is used as quality standards in food in amount $1.5 \mathrm{mg} / \mathrm{kg}$. From the result obtained the content of lead in sediments was obtained the value at point $\mathrm{B}$ and $\mathrm{C}$ that have been over limit, while the content of lead in Gonggong Snail at the three sampling area was obtained the value have been over limit.

Senggarang is one area that has ever been a mining area in Tanjungpinang city. The mining activities found in that area was a Bauxite Mining that had produced the waste from the washing liquid bauxite like red mud containing heavy metals, one of which is the Lead $(\mathrm{Pb})$ Heavy Metal [16].

Most of bauxite mining in Senggarang have been inactive since 2013. However, there are until now still active small mining. As a result of this mining, there are many red mud pools in this mining area. There are several other activities that can be found in Senggarang area such as residential area like stages houses near to coastal. The citizen who lived around the area are fisherman. They generally take the fish and other marine products on three areas sampling in this research.
The result of The area $\mathrm{A}$ in sediment measurement does not exceed the quality standards, it was caused the content of $\mathrm{Pb}$ contained in the sediment can be absorbed by the roots of mangroves, moreover the area A closed to the mangrove plants. Mastaller in Supriyantini (2015), stated the Mangrove has the ability to absorb organic materials and inorganic from the environment into the body through the cell membrane [14]. At area $\mathrm{C}$ showed a high content of $\mathrm{Pb}$ in the sediment that is equal to $41.37 \mathrm{mg} / \mathrm{kg}$. It can be caused by heavy metal waste in getting out of the former mining and machine fishing boats to catch Gongggong Snail settle for long time and it is difficult to re-dissolve in water, accordance to Lindsey in Makmur (2005), heavy metals bound in the sediments are relative difficult to dissolves in water, thus it made greater content of heavy metals inside. The existence of $\mathrm{Pb}$ in sediment showed that there has been a heaping of $\mathrm{Pb}$ contents in Senggarang coastal. The high concentration of heavy metals in sediment is possibly made by the deposition process that took place for long time caused heavy metals accumulated in sediment. Heavy metals were originally dissolved in the water adsorbed by the tiny particles which are deposited in the bottom of waters.

The overcome can be done by stopping the waste contributions from sewage contamination of the red mud pools excavated bauxite and doing reclamation to improve the post-mining environment condition. Post-mining land reclamation can also help improve soil quality as a result of excavation and washing minerals so that there are no new pollutioncontamination due to an excavated mine, located near to the coast of Senggarang. In addition, the mangrove cultivation can also be done to absorb heavy metals existing in the sediments as it is $t$ proposed [14], mangroves can absorb heavy metals in sediment.

The measurements of lead metal content result related to Gonggong snails at the Areas A, B and C already exceed the quality standards of ISO 7387: 2009 related to the maximum contamination limit of lead $(\mathrm{Pb})$ in the food that namely $1.5 \mathrm{mg} / \mathrm{kg}$. The higher the content of Lead $(\mathrm{Pb})$ in sediment, the higher content of lead $(\mathrm{Pb})$ in Gonggong Snail, The Sediment which has important role as a place to live for Gonggong and as a result of precipitation from 
seawater can affect the content of heavy metals contained in the water, the heavy metals in the waterworks will have the deposition process and be accumulated in sediment. Then it will be accumulated in Gonggong snails meat that live in bottom of waterworks. The ability to accumulate metals (bioaccumulation) through the food chain, may cause biologically hazardous materials metabolism and may affect the organisms that exist in that waterwork [2].

The content of $\mathrm{Pb}$ in Gonggong Snail already exceeded the quality standard.The heavy metals that had been accumulated in the tissues of shells or snails body will be growing much more when shells or snails that live in aquatic environments containing high heavy metals and will not be dispossed through feces [17]. As this type of Gonggong Snail is a type of organism that mobility is slow, accordance to Payung (2013), types of soft animals that do not move or slow mobility, cannot properly excrete metals $\mathrm{Pb}$ thus it will be continuously accumulated in body tissues [2], [4].

Gonggong Snails is one type of sea snails or gastropod, popularly known as the seafood in the Riau Archipelago and its surroundings. Gonggong Snails are used to meet daily food needs and extra livelihood by the local community. These herbivorous animals habitat can be found in coastal waterwork with a base of sand and mud.

Animals that live on the water and immerse themselves or active on the surface of the base, Gonggong Snails feed on by pulling microscopic organisms from the waterwork and sediments, where the chemicals substance such as $\mathrm{Pb}$ deposited in the sediment will be accumulated in Gonggong Snail meat, if it is consumed by humans in the great number of, it will be at high risk to health. Fardiaz in suksmerri (2008), said Pb metals in the human body can not be left overall from the body, it is approximately $5 \%-10 \%$ of the amount ingested will be adsorbed by the digestive system [13]. The effect of $\mathrm{Pb}$ toxicity will be seen when a person consumes $\mathrm{Pb}$ more than $2 \mathrm{mg}$ per day, the limit of $\mathrm{Pb}$ metal that is permitted to comsume is $0.2-2.0 \mathrm{mg}$ per day [13].

Gonggong Snails meat containing Pb Metal that has aready passed the quality standard, if it is consumed in a great number of may arise out a risk for health. Azhar (2011), said $\mathrm{Pb}$ acute poisoning may cause brain dysfunction, growth, liver and kidney dysfunction. Poisoning caused by the presence of $\mathrm{Pb}$ in the body influnce many tissues and organs systems. The Organs that become the target of a poisoning incident of $\mathrm{Pb}$ are the nervous system, renal system, reproductive system, and heart [3].Pb toxicity is chronical and acute. Chronical exposure can lead to fatigue, lethargy, irritability disorders, gastrointestinal disorders, depression, headaches, difficulty concentrating, impaired memory and difficult sleep. Acute toxicity may occur if $\mathrm{Pb}$ join in the body through food in a relatively short time with high doses may cause some symptoms such as abdominal cramps, nausea, vomiting, headaches, stupor, and coma [15].

The decrease of $\mathrm{Pb}$ in Gonggong meat can be conducted by soaking Gonggong meat into leaves and citrus fruits [18]. The type of the genus Citrus plants, is a material that can be used to bind metals, because they can catalize oxidation of flavor and color components. This type is also safe to use on food.

The result of this study is the heavy metal content (lead) in the sediment will affect the content of metals in aquatic biota. Waterworks that have heavy metal pollution should have special attention before giving adverse impact to the environment, especially for living organisms and humans.

\section{CONCLUSION}

1. The content of lead $(\mathrm{Pb})$ in Gonggong ranged from $4.63 \mathrm{mg} / \mathrm{kg}$ to $6.77 \mathrm{mg} / \mathrm{kg}$, with the average $5: 39 \mathrm{mg} / \mathrm{kg}$ and has already exceeded the quality standards based on ISO 7387: 2009 related to the maximum contamination limit of lead $(\mathrm{Pb})$ in food is $1.5 \mathrm{mg} / \mathrm{kg}$.

2. The content of lead $(\mathrm{Pb})$ in sediment ranged from $29.40 \mathrm{mg} / \mathrm{kg}$ to $41.37 \mathrm{mg} / \mathrm{kg}$, with the average $36.48 \mathrm{mg} / \mathrm{kg}$. This result has already exceeded the quality standards based on the Sediment Quality Guidelines, the limit of contamination Metals Lead $(\mathrm{Pb})$ in sediment of $30.2 \mathrm{mg} / \mathrm{kg}$ for coastal and marine waters.

\section{REFERENCES}

[1] H. Azhar, "The Study of Heavy Metal Content of $\mathrm{Pb}, \mathrm{Cu}, \mathrm{Cd}, \mathrm{Cr} \mathrm{On}$ Scallop Shells, Water and Sediment in Water Wedung, Demak: Semarang," Faculty of Fisheries and Marine Sciences University of Diponegoro, Semarang.1998. 
[2] S.Nasution, "The Content of Heavy Metals Lead (Pb) On Sediment and Stombus canarium Snails in Bintan Island Beach.," Pekanbaru-Riau University.2008.

[3] H.Palar, Heavy Metal Contamination and Toxicology, Jakarta: Rineka Copyright, 2008.

[4] F.I.Payung, "Content Studies and Spatial Distribution of Heavy Metals of Lead $(\mathrm{Pb})$ in sediment and mussels (Anadara Sp)," Makasar: Facultyl of Public Health UNHAS, 2008.

[5] Riau Archipelago Province Profile, 2012

[6] S.Ridhowati, Introduction to Variety Heavy Metals Pollution, Graha Science: Yogyakarta, 2013.

[7] Rifardi, Modern Ecology Marine Sediment, UNRI Press, Pekanbaru, 2008.

[8] (2013) Rusdianto: Available:http://kepri.antaranews.com/berita/ 27190/senggarang-besar-sarang-penambangan-bauksit-ilegal accessed on February 23, 2016

[9] A.O.Saliandri," Analisis Cemaran Logam Berat Pb, Cu, dan Zn pada ikan lele di tambak TPA Ganet Kota Tanjungpinang 2015,'Tanjungpinang: Environmental health, Poltekkes Kemenkes Tanjungpinang, 2015.

[10] Sedimen Quality Guidelines

(SQC) http://www.csun.edu/ dorsogna/nodrill/ RospoMare/ecotoxicology.pdf accessed on : 18 April 2016. 21:37 WIB.

[11] SNI 7387, Limitation for Heavy Metal contamination on Food ,2009.

[12] D.N.Sitepu, "Concentration of Heavy Metals $\mathrm{Pb}, \mathrm{Cu}$ and $\mathrm{Zn}$ in Gonggong Snail (Strombus Canarium) From Sungai Enam and Dompak," Faculty of Fisheries and Marine Resources University of Riau: Pekanbaru, 2015

[13] Suksmerri, "The effect of Metal Lead (Pb) Pollution on Health, ".http://jurnal.fkm.unand.ac.id/index.php/jkma/article/downloa $\mathrm{d} / 34 / 65,2008$

[14] E.Supriyantini, "The Content of Lead $(\mathrm{Pb})$ Heavy Metals and Copper (Cu) On Roots and Fruits of Mangrove Avicenna Marina in the waterworks at Tanjung Emas Semarang," University Diponegoro: Semarang, 2015.

[15] W.Widowati, The Effects of Toxic Metals Prevention and Pollution Control : Andi Offset :Yogyakarta, 2008.

[16] A.Zulfikar, "Content Analysis of Metals in Tailings Waste (Red and Mud)," Tanjungpinang: Faculty of Fisheries and Marine Maritime University Raja Ali Haji University, 2011.

[17] Suwarsito, "Spatial Analysis of Heavy Metals Pollution in the Sediment and Biota Water in estaury of Serayu river," The Faculty of Education, University of Muhammadiyah Purwokerto, 2013.

[18] C.Abadina, The Decrease Levels of Lead $(\mathrm{Pb})$ on shell by Using Acid. Surabaya: Environmental Engineering; Adi Buana Surabaya Univeristy, 2012. 